\title{
Risk of COVID-19 infection in MS and neuromyelitis optica spectrum disorders
}

Moli Fan, MD, PhD, * Wei Qiu, MD, PhD, * Bitao Bu, MD, PhD, * Yan Xu, MD, PhD, * Huan Yang, MD, Dehui Huang, MD, Alexander Y. Lau, MD, Jun Guo, MD, PhD, Mei-Ni Zhang, MD, Xinghu Zhang, MD, PhD, Chun-Sheng Yang, MD, PhD, Jingshan Chen, MD, Pei Zheng, MD, Qiang Liu, MD, PhD, Chao Zhang, MD, PhD, and Fu-Dong Shi, MD, PhD

Neurol Neuroimmunol Neuroinflamm 2020;7:e787. doi:10.1212/NXI.0000000000000787

\section{Abstract}

\section{Objective}

Disease-modifying drugs (DMDs) may alter the immune status and thus increase the susceptibility to coronavirus disease 2019 (COVID-19) in patients with MS or neuromyelitis optica spectrum disorders (NMOSD). However, evidence supporting this notion is currently lacking. In this study, we conducted a survey on the risk of COVID-19 in patients with MS and NMOSD.

\section{Methods}

The survey was conducted through the Chinese Medical Network for Neuroinflammation. Patients in 10 MS centers from 8 cities including Wuhan were included. Information about MS and NMOSD disease duration and the usage of DMDs were collected. Data of suspected cases of COVID-19 were obtained from hospital visits, questionnaires, and patient self-reporting. Severe acute respiratory syndrome coronavirus 2 (SARS-CoV-2) infection was confirmed through clinical evaluation by a panel of experts in conjunction with chest CT and viral RNA detection.

\section{Results}

Eight hundred eighty-two of 1,804 (48.89\%) patients with MS and 2,129 of 3,060 (69.58\%) patients with NMOSD were receiving DMDs. There were no alterations in the patients' DMD regimen during January 15, 2020, to March 15, 2020, the 3-month period. None of the patients with MS treated with DMDs had COVID-19. However, 2 patients with relapsing NMOSD were diagnosed with COVID-19-related pneumonia. After treatment, both patients recovered from pneumonia and neither patient experienced new attacks due to predisposing SARS-CoV-2 infection in the following 2 months.

\section{Conclusions}

No increased risk of COVID-19 infection was observed in patients with MS or NMOSD, irrespective of whether these patients received DMDs. A battery of stringent preventive measures adopted by neurologists to reduce COVID-19 infection in these patients may have contributed to low risk of COVID-19 infection.

\author{
Correspondence \\ Dr. Shi
}

fshi@tmu.edu.cn
MORE ONLINE

\section{COVID-19 Resources}

For the latest articles, invited commentaries, and blogs from physicians around the world

NPub.org/COVID19

\footnotetext{
*These authors contributed equally to this work.

From the Department of Neurology (M.F., H.Y., J.C., P. Zheng., C. Zhang, F.-D.S.), Tianjin Medical University General Hospital; China National Clinical Research Center for Neurological Diseases (X. Zhang, F.-D-.S.), Jing-Jin Center for Neuroinfalmmation Beijing Tiantan Hospital, Capital Medical University; Department of Neurology (W.Q.), the Third Affiliated Hospital of Sun Yat-sen University, Guangzhou; Department of Neurology (B.B.), Tongji Hospital Affiliated to Tongji Medical College, Huazhong University of Science and Technology, Wuhan; Department of Neurology (Y.X.), Peking Union Medical College Hospital, Beijing; Xiangya Hospital of Central South University (H. Yang), Changsha; Department of Neurology (D. Huang), General Hospital of Chinese People's Liberation Army, Beijing; Division of Neurology (A.Y.L.), Department of Medicine and Therapeutics, Prince of Wales Hospital, the Chinese University of Hong Kong; Department of Neurology (J.G.), Tangdu Hospital, Air Force Military Medical University, Xi'an; Department of Neurology (M. Zhang), the First Affiliated Hospital of Shanxi Medical University, Taiyuan, China.
}

Go to Neurology.org/NN for full disclosures. Funding information is provided at the end of the article.

The Article Processing Charge was funded by the authors.

This is an open access article distributed under the terms of the Creative Commons Attribution-NonCommercial-NoDerivatives License 4.0 (CC BY-NC-ND), which permits downloading and sharing the work provided it is properly cited. The work cannot be changed in any way or used commercially without permission from the journal. 


\section{Glossary}

CMNN = Chinese Medical Network for Neuroinflammation; COVID-19 = coronavirus disease 2019; DMD = diseasemodifying drug; NMOSD = neuromyelitis optica spectrum disorder; SARS-CoV-2 = severe acute respiratory syndrome coronavirus 2 .

The number of the novel coronavirus disease 2019 (COVID19) cases and mortality grow rapidly around the world. Aged individuals with preexisting medical conditions are at increased risk for severe acute respiratory syndrome coronavirus 2 (SARS-CoV-2) infection, with disease and mortality occurring predominantly in this group. ${ }^{1-3}$ It is thus conceivable that patients with MS or neuromyelitis optica spectrum disorders (NMOSDs) who are receiving disease-modifying treatments have increased susceptibility to COVID-19 infection and disease. However, evidence supporting this notion is currently lacking.

\section{Methods}

We have conducted a survey through the Chinese Medical Network for Neuroinflammation (CMNN). The CMNN consists of neurologists specialized in managing patients with MS and NMOSD from 47 hospitals across China (figure 1). MS and NMOSD were diagnosed according to the 2017 McDonald criteria and 2015 International Panel for Neuromyelitis Optica Diagnosis criteria, respectively. All patients with MS and NMOSD managed in 10 centers from 8 cities including Wuhan were enrolled in this study. Information about disease duration and usage of disease-modifying drugs (DMDs) were collected. Data of suspected cases of COVID19 were obtained from hospital visits, online questionnaires (supplementary file, links.lww.com/NXI/A266), and patient self-reporting via emails or phone calls. Patients who did not respond to questionnaires were excluded from this study. Confirmation of SARS-CoV-2 infection was determined through clinical evaluation by a panel of experts in conjunction with a set of tests including chest CT and viral RNA detection by real-time fluorescent PCR from nasopharyngeal swab samples.

\section{Data availability}

All data are published in this article.

\section{Results}

We conducted a survey for COVID-19 infection during January 15 to March 15 . One thousand eight hundred four of

Figure 1 Distribution map of hospitals of the Chinese Medical Network for Neuroinflammation (CMNN)

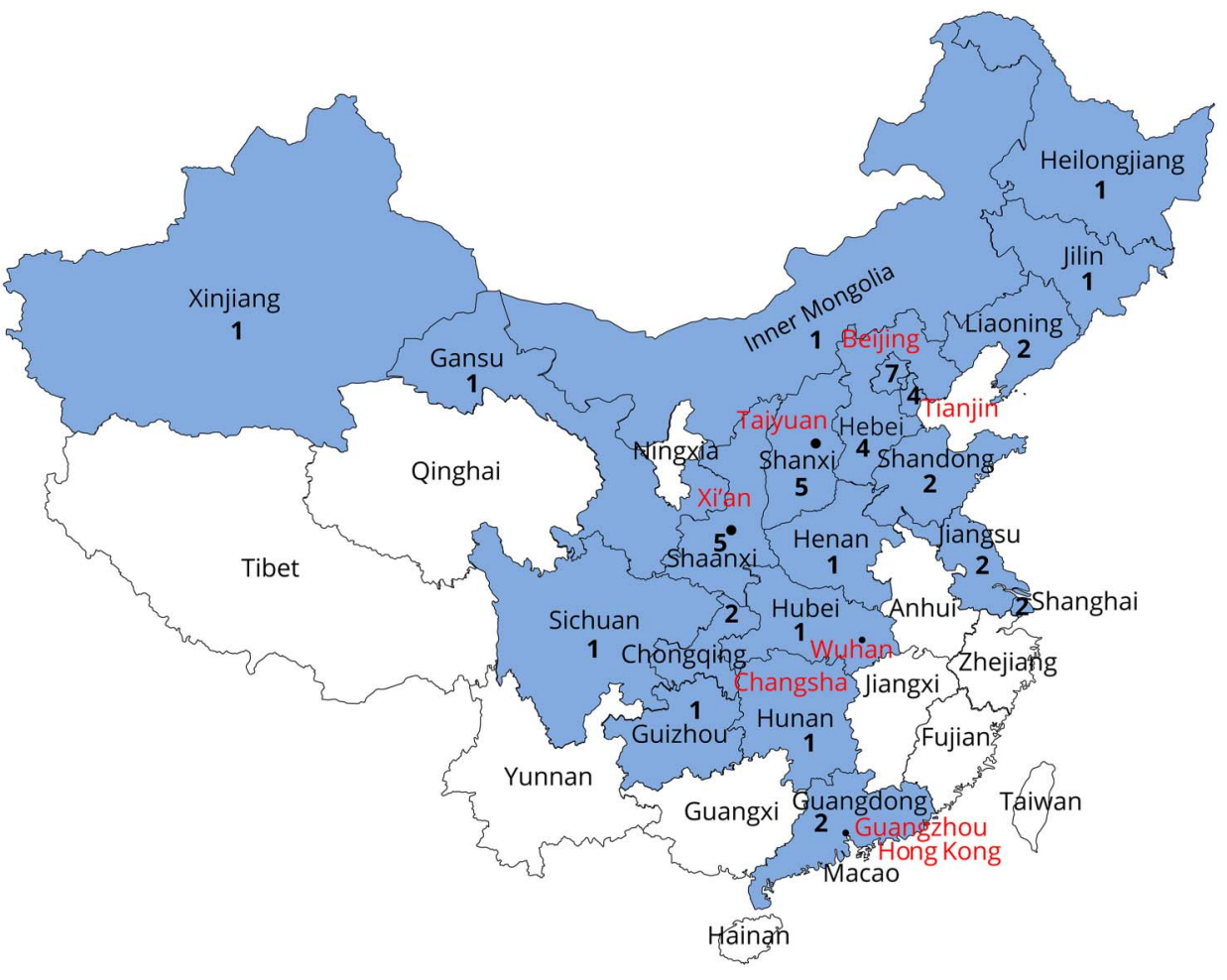

The cities marked red were surveyed for the usage of disease-modifying drugs. The CMNN was founded on February 25,2018 . It is a branch of the China National Clinical Research Center for Neurological Diseases. Until now, members of the CMNN include 47 hospitals from 21 provinces and municipalities in mainland China. The location and number of hospitals are illustrated. CMNN's mission includes consultation for government policy-making, introduction of disease-modifying drugs into the National Reimbursement Drug List, fostering research collaborations, and educating neuroimmunologists. 
1,836 (98.26\%) patients with MS and 3,060 of 3,128 (97.82\%) patients with NMOSD from 10 MS/NMOSD centers across China, including Tongji Hospital from Wuhan, have responded (figure 2). The mean disease duration was 4.64 years for patients with MS and 4.94 years for patients with NMOSD. For MS, 882 (48.89\%) patients were receiving DMDs, and the remaining patients received nonDMDs such as corticosteroids, traditional Chinese medicines, or other drugs. For NMOSD, 2,129 (69.58\%) patients were receiving DMDs. There were no alterations in the patients' DMD regimen during this 3-month period (table, figures 3 and 4). None of the patients with MS treated with DMDs were diagnosed with COVID-19. However, 2 patients with relapsing NMOSD, a 53-year-old man from Wuhan and a 49-year-old man from Beijing, were diagnosed with COVID-19-related pneumonia, and SARS-CoV-2 infection was confirmed by viral RNA detection. Both patients had received oral methylprednisolone as maintenance therapy to prevent relapses, and neither had been treated with other DMDs after diagnosis. After treatment according to the Chinese protocols for COVID-19, ${ }^{4}$ both patients recovered from pneumonia and neither patient experienced new attacks due to predisposing SARS-CoV-2 infection in the following 2 months. Neurologists from centers who have not contributed to these data have reported no COVID-19infected patients with MS or NMOSD diagnosed in their clinic.

\section{Discussion}

Natalizumab, rituximab, and fingolimod usage is associated with reactivation of John Cunningham virus and progressive multifocal leukoencephalopathy in patients with MS. ${ }^{5}$ Side effects for newer therapies such as eculizumab, inebilizumab, satralizumab, and tocilizumab in NMOSD are unclear, partly because of the relatively short duration and small numbers of patients' exposure to these medications. Because these DMDs interfere with multiple arms of the immune system, altered immune functions in these patients are expected. Despite this anticipated risk, we did not observe an escalated rate of COVID-19 infection, even at the epicenter of the outbreak in Wuhan. SARS-CoV-2 has spread to all the provinces of China from the Wuhan epicenter since January 2020. The overall incidence of COVID-19 infection in China is estimated at $6 / 10^{5}$ subjects comparable with the estimated incidence of NMOSD in China. These results from China are consistent with observations in some MS centers from Korea, Japan, and Singapore where no COVID-19 cases have been reported for patients with MS or NMOSD treated with DMDs (personal communications). As with the general public, patients with MS and NMOSD do not have immunity to SARS-CoV-2, and altered immunity induced by DMDs in patients with MS or NMOSD, if any, appears insufficient to enhance the susceptibility to infection.

Figure 2 Distribution map of COVID-19 cases across China and cities and hospitals surveyed (red) for this study

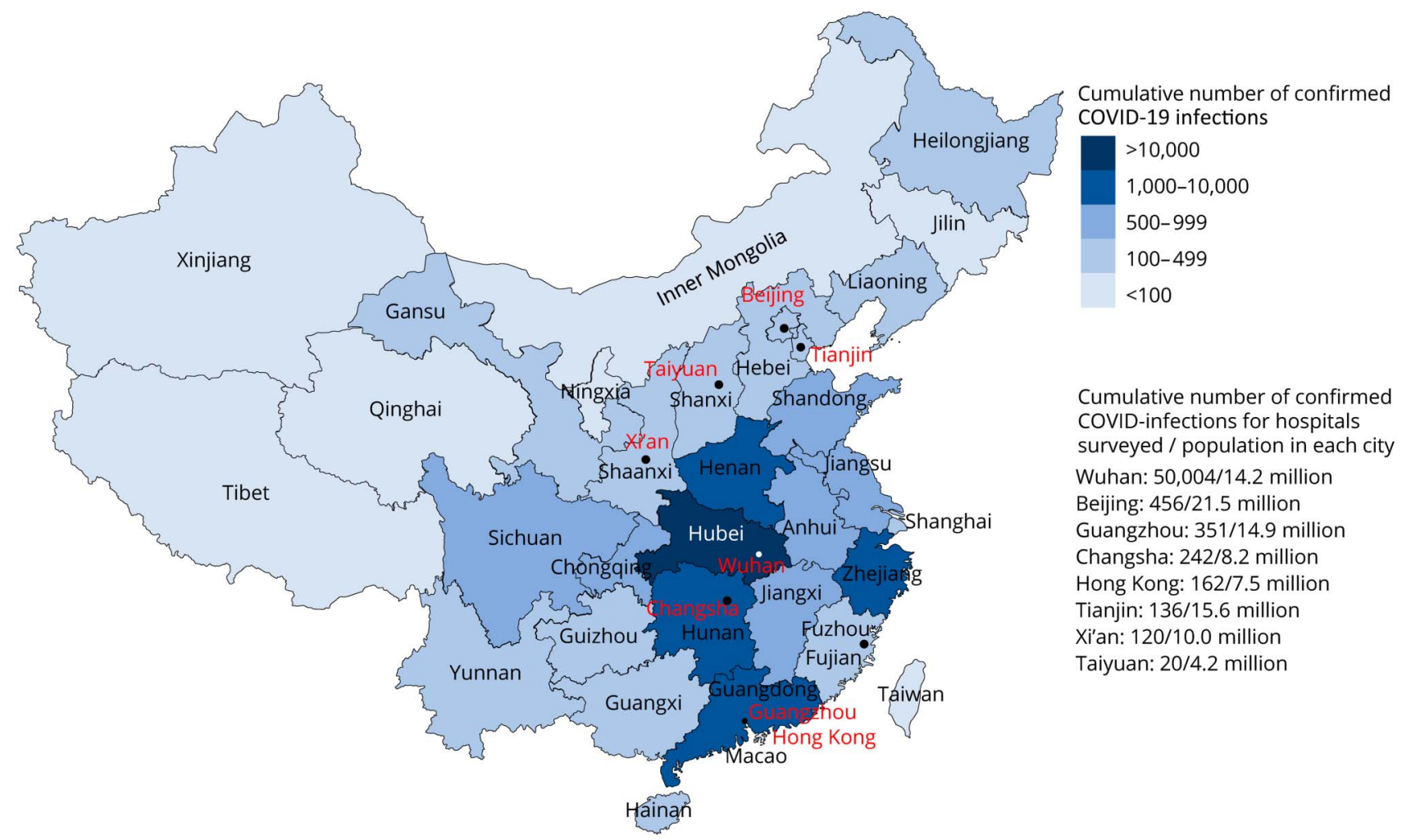

COVID-19 = coronavirus disease 2019. 
Table DMDs used by MS and NMOSD patients and confirmed COVID-19 cases in 10 centers from 8 cities in China

\begin{tabular}{|c|c|c|c|c|c|c|c|c|c|}
\hline \multirow[b]{2}{*}{ Characteristics } & \multicolumn{9}{|c|}{ Cities of MS/NMOSD centers surveyed } \\
\hline & Wuhan & Beijing & Guangzhou & Changsha & Hong Kong & Tianjin & Xi'an & Taiyuan & Total \\
\hline Population (million) & 14.2 & 21.5 & 14.9 & 8.2 & 7.5 & 15.6 & 10.0 & 4.2 & 96.1 \\
\hline No. of patients with MS & 78 & $796^{\mathrm{a}}$ & 350 & 152 & 160 & 90 & 34 & 144 & 1804 \\
\hline Disease duration, mean, $y$ & 6.63 & 1.9 & 7 & 4.55 & 11.45 & 4.61 & 5.96 & 5.2 & 4.64 \\
\hline Interferon beta & $9(11.50)$ & $51(6.63)$ & $5(1.43)$ & $14(9.21)$ & $34(21.26)^{b}$ & 0 & $1(2.94)$ & $45(31.25)$ & $159(8.81)$ \\
\hline Teriflunomide & $30(38.50)$ & $226(29.39)$ & $91(26.00)$ & $42(27.63)$ & $20(12.50)$ & $30(33.33)$ & $9(26.47)$ & $27(18.75)$ & $475(26.33)$ \\
\hline Fingolimod & 0 & $27(3.51)$ & $2(0.57)$ & 0 & $31(19.38)$ & $1(1.25)$ & $2(5.88)$ & 0 & $63(3.49)$ \\
\hline Rituximab & $6(7.70)$ & $12(1.56)$ & $34(9.71)$ & 0 & $4(2.50)$ & $25(31.25)$ & $15(44.12)$ & $12(8.33)$ & $108(5.99)$ \\
\hline Dimethyl fumarate & 0 & $1(0.13)$ & $6(1.71)$ & 0 & $39(24.38)$ & 0 & 0 & 0 & $46(2.55)$ \\
\hline Cladribine & 0 & 0 & 0 & 0 & $6(3.75)$ & 0 & 0 & 0 & $6(0.33)$ \\
\hline COVID-19 confirmed & 0 & 0 & 0 & 0 & 0 & 0 & 0 & 0 & 0 \\
\hline No. of patients with NMOSD & 588 & $1,079^{c}$ & 450 & 453 & 30 & 155 & 158 & 147 & 3,060 \\
\hline Disease duration, mean, $y$ & 5.87 & 3.8 & 6 & 3.75 & 12.69 & 5.52 & 5.5 & 7.2 & 4.94 \\
\hline DMDs, $\mathbf{n}(\%)$ & $420(71.43)$ & $697(64.6)$ & 375 (83.33) & $268(59.16)$ & $22(73.33)$ & $100(64.52)$ & $150(94.94)$ & $97(65.99)$ & $2,129(69.58)$ \\
\hline Methylprednisolone $^{d}$ & $36(6.12)$ & $30(2.78)$ & $412(91.56)$ & $113(24.94)$ & 4 13.33) & $55(35.48)$ & $8(5.06)$ & $137(93.20)$ & 795 (25.98) \\
\hline Azathioprine $^{e}$ & $18(3.06)$ & $104(9.64)$ & $180(40.00)$ & $65(14.40)$ & $12(40.00)$ & $2(1.29)$ & $7(4.43)$ & $17(11.56)$ & $405(13.24)$ \\
\hline Mycophenolate mofetil & $24(4.08)$ & $439(40.69)$ & $146(32.44)$ & $173(38.15)$ & $6(20.00)$ & $6(3.87)$ & $6(3.80)$ & $32(21.77)$ & $832(27.19)$ \\
\hline Tacrolimus & $360(61.22)$ & $17(1.58)$ & $14(3.11)$ & $12(2.60)$ & 0 & 0 & 0 & 0 & $403(13.17)$ \\
\hline Rituximab & $12(2.04)$ & $93(8.62)$ & $29(6.44)$ & $18(3.94)$ & $3(10.00)$ & $55(35.48)$ & $137(86.71)$ & $34(23.135)$ & $381(12.45)$ \\
\hline Tocilizumab & 0 & $10(0.93)$ & $6(1.33)$ & 0 & 0 & $35(22.58)$ & 0 & $11(7.48)$ & $62(2.03)$ \\
\hline Cyclophosphamide & 0 & $34(3.15)$ & 0 & 0 & 0 & $2(1.29)$ & 0 & $3(2.04)$ & $39(1.27)$ \\
\hline COVID-19 confirmed & 1 & 1 & 0 & 0 & 0 & 0 & 0 & 0 & 2 \\
\hline
\end{tabular}

Abbreviations: COVID-19 = coronavirus disease 2019; DMD = disease-modifying drug; NMOSD = neuromyelitis optica spectrum disorder.

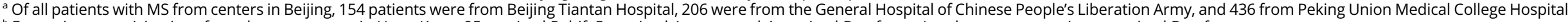
${ }^{\mathrm{b}}$ For patients receiving interferon beta treatment in Hong Kong, 25 received Rebif, 5 received Avonex, and 4 received Betaferon. In other centers, patients received Betaferon treatment.

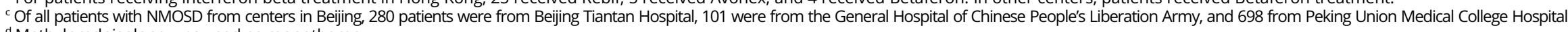

"Methylprednisolone was used as monotherapy.

e A proportion of patients who received treatment with immunosuppressants used concomitant methylprednisolone. 
Figure 3 Proportions of patients with MS in 10 centers from 8 cities surveyed who received disease-modifying drugs and methylprednisolone

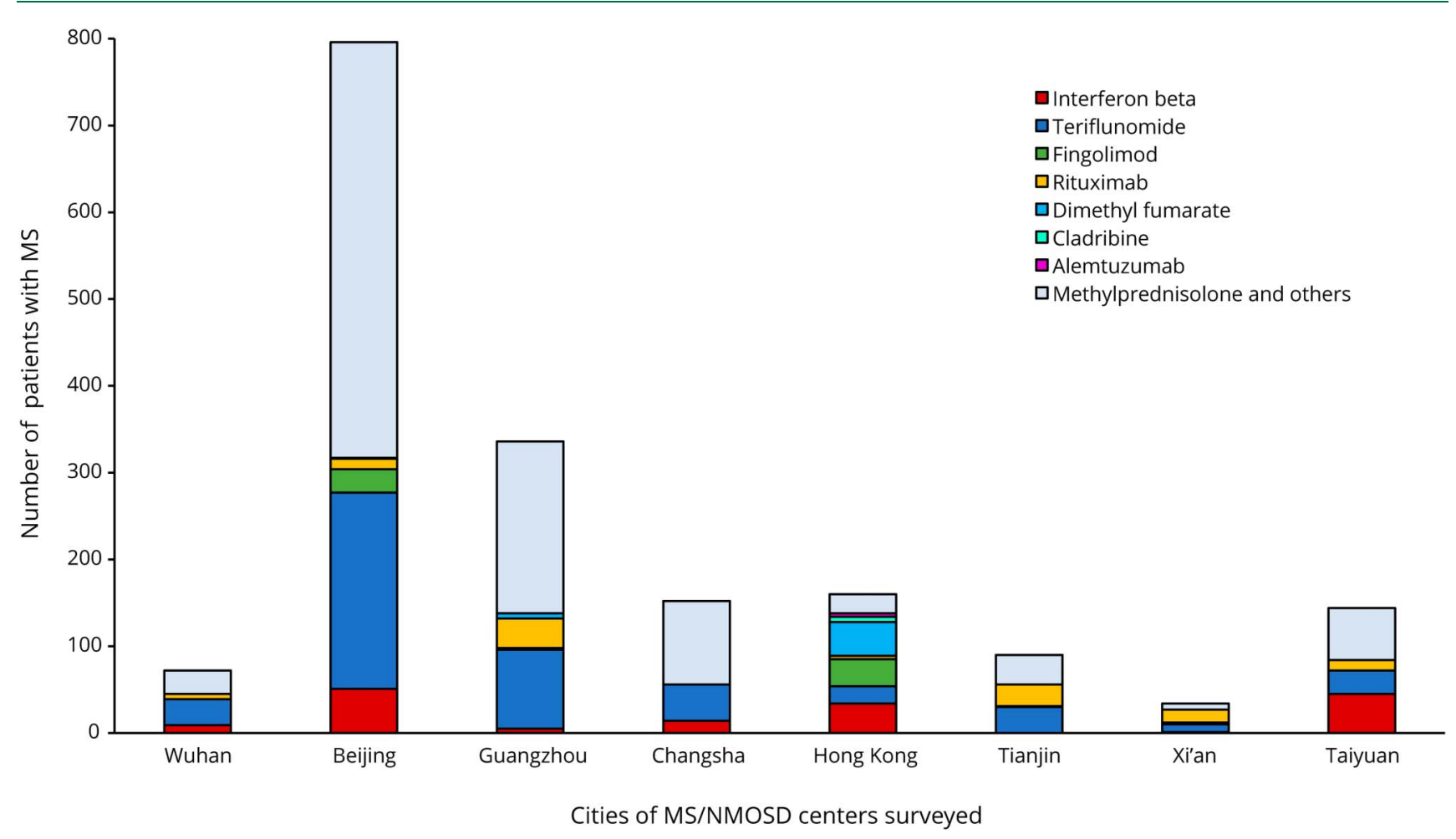

COVID-19 = coronavirus disease 2019; NMOSD = neuromyelitis optica spectrum disorder.

From the start of the SARS-CoV-2 epidemic in December 2019 and during its progression in China, neuroimmunologists have paid special attention to their patients with MS and NMOSD receiving DMDs who are at increased risk for infection. Meticulous preventive protocols have been adopted, which have undoubtedly minimized the exposure of these at-risk patients, and thereby have contributed to the absence or low rates of SARS-CoV-2 infection in our patients. These measures include but are not limited to the following: scaling up viral test capacities and swift isolation of infected patients, online patient consultations to reduce visits to hospitals, and coordinating patients with local care givers to perform infusions and routine monitoring. Moreover, new patients or those with a suspected new MS or NMOSD attack were segregated in special hospital units with single rooms, which is not a common practice in Chinese inpatient facilities. Portions of the Department of Neurology have further been reconfigured to accommodate patients with suspected infected. Visits from friends and relatives have been strictly controlled.

This study has several limitations. Self-reporting and questionnaires may have missed some patients, especially those who had minor symptoms. In rare cases, patients refused to disclose this information to avoid mandatory quarantine in designated facilities. One aspect of the DMDs available for patients from mainland China and durations on DMDs differs from those in other countries. Specifically, natalizumab, cladribine, and alemtuzumab are not available to the patients from mainland China. Nevertheless, the collection of DMDs used by patients from Hong Kong, Korea, Japan, and Singapore are similar to those used in the United States and EU, implying the generality of our conclusions.

Despite these limitations, our data originated from a large number of patients that include individuals from the hardest hit city of Wuhan and its surrounding regions, arguing against a significantly increased risk of COVID-19 infection and disease in patients with MS and NMOSD treated with DMDs. However, a variety of stringent measures that have been taken to protect these patients must have contributed to relative low risk of COVID-19 infection in our cohort. Because COVID-19 has already infected 3,387 medical professionals and has caused 28 deaths among them in China, extraordinary steps in managing neurologic patients to protect both patients and medical professionals from COVID-19 infection are critically important. Because COVID-19 is becoming a serious global health concern ${ }^{6}$ and its spread is still intensifying in many parts of the world, a full-scale preparedness plan, with unconditional support for manpower and resources from federal and local governments, is required to better manage neurologic patients during the pandemic. 
Figure 4 Proportions of patients with NMOSD in 10 centers from 8 cities surveyed who received disease-modifying drugs and methylprednisolone

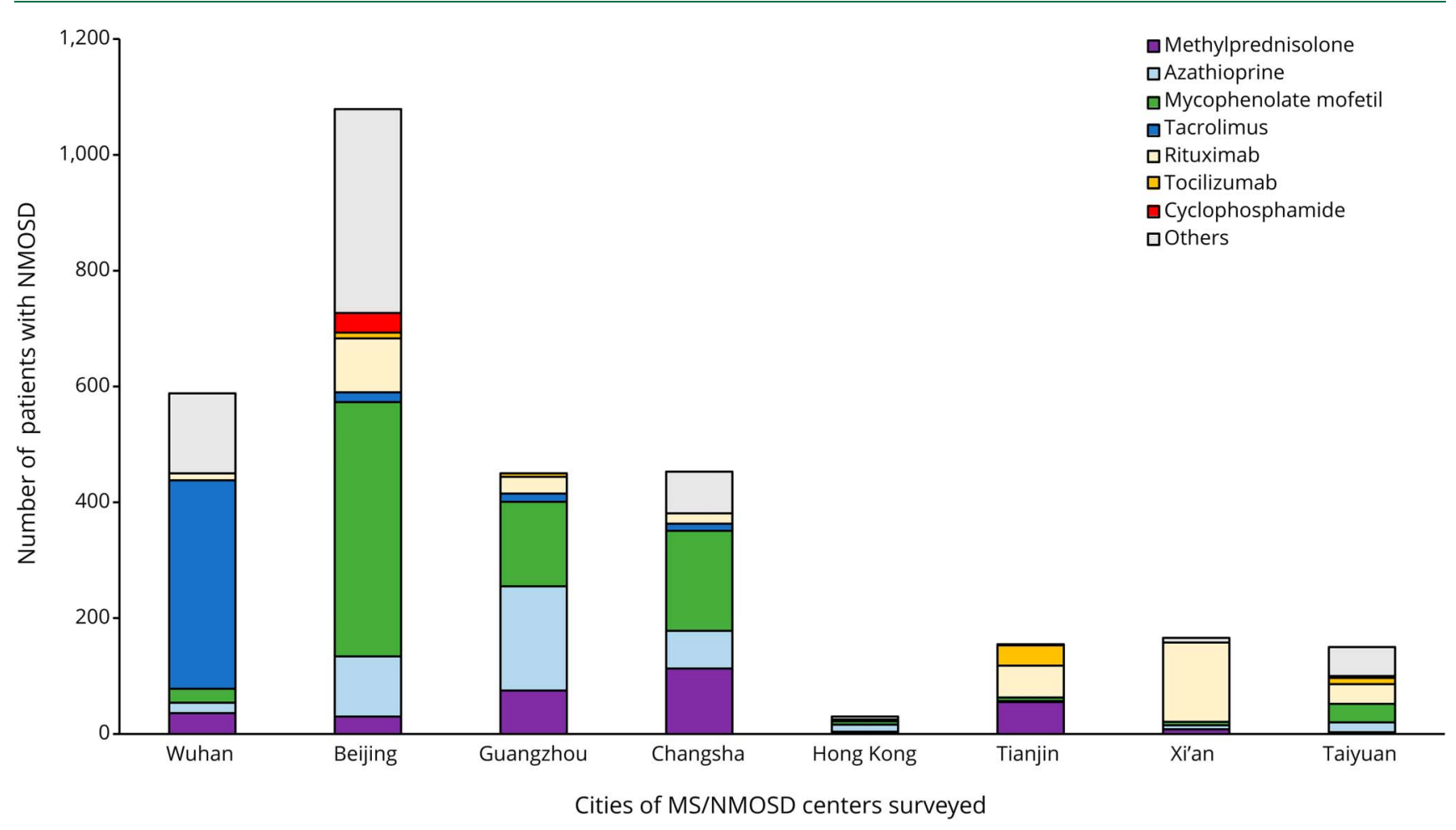

COVID-19 = coronavirus disease 2019; NMOSD = neuromyelitis optica spectrum disorder.

\section{Dedication}

This article is dedicated to our colleagues Bin Zhao, Guangxun Yan, Yuanyuang Qu, Shasha Han, Mengxi Li, Lianghui Yang, Lei Su, Jing Xu, Mengya Xing, Zhe Zhang, Jinmei Wang, Wei-Na Jin from the Departments of Neurology, Tianjin Medical University General Hospital and Beijing Tiantan Hospital, and to those medical professionals across China, who went to Wuhan, and Departments of Infectious Disease caring for patients with COVID-19.

\section{Acknowledgment}

The authors thank the following neurologist colleagues for sharing information on the risk of COVID-19 infections in their clinics: Kazuo Fujihara, MD (Department of Multiple Sclerosis Therapeutics, Fukushima Medical University School of Medicine, Japan); Ho Jin Kim, MD, PhD (Division of Clinical Research, Research Institute \& Hospital of National Cancer Center, Korea); Kevin Tan, BM BS, MRCP (UK) (Department of Neurology, National Neuroscience Institute, Singapore); Weibin Liu, MD (The First Affiliated Hospital of Sun Yat-sen University, Guangzhou); Ying Fu, MD (The First Affiliated Hospital of Fujian Medical University, Fuzhou); Xiaokun Qi, MD (The Navy General Hospital, Beijing); Guangzhi Liu, MD (Beijing Anzhen Hospital, Capital Medical University, Beijing); Zeyu Li, MD (The Affiliated Hospital of Inner Mongolia Medical
University, Hohhot); Jiawei Wang, MD (Beijing Tongren Hospital, Capital Medical University, Beijing); Lihua Wang, MD (The 2nd Affiliated Hospital of Harbin Medical University, Harbin); Tao Jin, MD (First Hospital of Jilin University, Changchun); Manxia Wang, MD (The Second Hospital of Lanzhou University, Lanzhou); Xiangjun Chen, MD (Huashan Hospital Fudan University, Shanghai). The authors also thank D.-C. Tian, K.-B. Shi, and members of Jing-Jin Neuroimmunology team for extensive support; Drs. Luc Van Kear and Samuel X. Shi for English editing.

\section{Study funding}

This study was supported by the Advanced Innovation Center for Human Brain Protection (Neuroimmune 01), and the National Science Foundation of China (91642205, 81830038, and 81601019).

\section{Disclosure}

The authors report no disclosures relevant to the manuscript. None of the funding organizations were involved in the design and conduct of the study; collection, management, analysis, and interpretation of the data; preparation, review, or approval of the manuscript; or the decision to submit the manuscript for publication. Go to Neurology.org/NN for full disclosures.

\section{Publication history}

Received by Neurology: Neuroimmunology \& Neuroinflammation April 20, 2020. Accepted in final form April 27, 2020. 
Appendix Authors

\begin{tabular}{|c|c|c|}
\hline Name & Location & Contribution \\
\hline $\begin{array}{l}\text { Moli Fan, } \\
\text { MD, PhD }\end{array}$ & $\begin{array}{l}\text { Department of Neurology, } \\
\text { Tianjin Medical University } \\
\text { General Hospital, China }\end{array}$ & $\begin{array}{l}\text { Data collection, statistical } \\
\text { analysis, data } \\
\text { interpretation, and } \\
\text { administrative, technical, or } \\
\text { material support }\end{array}$ \\
\hline $\begin{array}{l}\text { Wei Qiu, } \\
\text { MD, PhD }\end{array}$ & $\begin{array}{l}\text { Department of Neurology, } \\
\text { the Third Affiliated Hospital } \\
\text { of Sun Yat-sen University, } \\
\text { Guangzhou, China }\end{array}$ & $\begin{array}{l}\text { Data collection, statistical } \\
\text { analysis, and data } \\
\text { interpretation }\end{array}$ \\
\hline $\begin{array}{l}\text { Bitao Bu, } \\
\text { MD, PhD }\end{array}$ & $\begin{array}{l}\text { Department of Neurology, } \\
\text { Tongji Hospital affiliated to } \\
\text { Tongji Medical College, } \\
\text { Huazhong University of } \\
\text { Science and Technology, } \\
\text { Wuhan, China }\end{array}$ & $\begin{array}{l}\text { Data collection, statistical } \\
\text { analysis, and data } \\
\text { interpretation }\end{array}$ \\
\hline $\begin{array}{l}\text { Yan Xu, } \\
\text { MD, PhD }\end{array}$ & $\begin{array}{l}\text { Department of Neurology, } \\
\text { Peking Union Medical College } \\
\text { Hospital, Beijing, China }\end{array}$ & $\begin{array}{l}\text { Data collection, statistical } \\
\text { analysis, and data } \\
\text { interpretation }\end{array}$ \\
\hline $\begin{array}{l}\text { Huan } \\
\text { Yang, MD, } \\
\text { PhD }\end{array}$ & $\begin{array}{l}\text { Department of Neurology, } \\
\text { Xiangya Hospital of Central } \\
\text { South University, Changsha, } \\
\text { China. }\end{array}$ & $\begin{array}{l}\text { Data collection, } \\
\text { statisticalanalysis, and data } \\
\text { interpretation }\end{array}$ \\
\hline $\begin{array}{l}\text { Dehui } \\
\text { Huang, } \\
\text { MD }\end{array}$ & $\begin{array}{l}\text { Department of Neurology, } \\
\text { General Hospital of Chinese } \\
\text { People's Liberation Army, } \\
\text { Beijing, China }\end{array}$ & $\begin{array}{l}\text { Data collection, statistical } \\
\text { analysis, and data } \\
\text { interpretation }\end{array}$ \\
\hline $\begin{array}{l}\text { Alexander } \\
\text { Y. Lau, MD }\end{array}$ & $\begin{array}{l}\text { Division of Neurology, } \\
\text { Department of Medicine and } \\
\text { Therapeutics, Prince of Wales } \\
\text { Hospital, The Chinese } \\
\text { University of Hong Kong, China }\end{array}$ & $\begin{array}{l}\text { Data collection, statistical } \\
\text { analysis, and data } \\
\text { interpretation }\end{array}$ \\
\hline $\begin{array}{l}\text { Jun Guo, } \\
\text { MD, PhD }\end{array}$ & $\begin{array}{l}\text { Department of Neurology, } \\
\text { Tangdu Hospital, Air Force } \\
\text { Military Medical University, } \\
\text { Xi'an, China }\end{array}$ & $\begin{array}{l}\text { Data collection, statistical } \\
\text { analysis, and data } \\
\text { interpretation }\end{array}$ \\
\hline $\begin{array}{l}\text { Mei-Ni } \\
\text { Zhang, MD }\end{array}$ & $\begin{array}{l}\text { Department of Neurology, } \\
\text { The First Affiliated Hospital } \\
\text { of Shanxi Medical } \\
\text { University, Taiyuan, China }\end{array}$ & $\begin{array}{l}\text { Data collection, statistical } \\
\text { analysis, and data } \\
\text { interpretation }\end{array}$ \\
\hline $\begin{array}{l}\text { Xinghu } \\
\text { Zhang, MD }\end{array}$ & $\begin{array}{l}\text { China National Clinical } \\
\text { Research Center for } \\
\text { Neurological Diseases, } \\
\text { Department of Neurology, } \\
\text { Beijing Tiantan Hospital, Capital } \\
\text { Medical University, China }\end{array}$ & $\begin{array}{l}\text { Data collection, statistical } \\
\text { analysis, and data } \\
\text { interpretation }\end{array}$ \\
\hline $\begin{array}{l}\text { Chun- } \\
\text { Sheng } \\
\text { Yang, MD, } \\
\text { PhD }\end{array}$ & $\begin{array}{l}\text { Department of Neurology, } \\
\text { Tianjin Medical University } \\
\text { General Hospital, China }\end{array}$ & $\begin{array}{l}\text { Data collection, statistical } \\
\text { analysis, and data } \\
\text { interpretation and } \\
\text { administrative, technical, or } \\
\text { material support }\end{array}$ \\
\hline
\end{tabular}

Appendix (continued)

\begin{tabular}{|c|c|c|}
\hline Name & Location & Contribution \\
\hline $\begin{array}{l}\text { Jingshan } \\
\text { Chen, MD }\end{array}$ & $\begin{array}{l}\text { Department of Neurology, } \\
\text { Tianjin Medical University } \\
\text { General Hospital, China }\end{array}$ & $\begin{array}{l}\text { Data collection, statistical } \\
\text { analysis, data } \\
\text { interpretation and } \\
\text { drafting of the manuscript, } \\
\text { and administrative, } \\
\text { technical, or material } \\
\text { support }\end{array}$ \\
\hline $\begin{array}{l}\text { Pei Zheng, } \\
\text { MD }\end{array}$ & $\begin{array}{l}\text { Department of Neurology, } \\
\text { Tianjin Medical University } \\
\text { General Hospital, China }\end{array}$ & $\begin{array}{l}\text { Data collection, statistical } \\
\text { analysis, data } \\
\text { interpretation and } \\
\text { drafting of the manuscript, } \\
\text { and administrative, } \\
\text { technical, or material } \\
\text { support }\end{array}$ \\
\hline $\begin{array}{l}\text { Qiang Liu, } \\
\text { MD, PhD }\end{array}$ & $\begin{array}{l}\text { Department of Neurology, } \\
\text { Tianjin Medical University } \\
\text { General Hospital, China }\end{array}$ & $\begin{array}{l}\text { Data collection, statistical } \\
\text { analysis, and data } \\
\text { interpretation and } \\
\text { drafting of the } \\
\text { manuscript }\end{array}$ \\
\hline $\begin{array}{l}\text { Chao } \\
\text { Zhang, } \\
\text { MD, PhD }\end{array}$ & $\begin{array}{l}\text { Department of Neurology, } \\
\text { Tianjin Medical University } \\
\text { General Hospital, China }\end{array}$ & $\begin{array}{l}\text { Data collection, statistical } \\
\text { analysis, data } \\
\text { interpretation, drafting } \\
\text { of the manuscript, } \\
\text { and administrative, } \\
\text { technical, or material } \\
\text { support }\end{array}$ \\
\hline $\begin{array}{l}\text { Fu-Dong } \\
\text { Shi, MD, } \\
\text { PhD }\end{array}$ & $\begin{array}{l}\text { Department of Neurology, } \\
\text { Tianjin Medical University } \\
\text { General Hospital, } \\
\text { China; China National } \\
\text { Clinical Research Center } \\
\text { for Neurological } \\
\text { Diseases, Jing-Jin Center } \\
\text { for Neuroinfalmmation, } \\
\text { Beijing Tiantan Hospital, } \\
\text { Capital Medical } \\
\text { University, } \\
\text { China }\end{array}$ & $\begin{array}{l}\text { Concept and design, } \\
\text { obtained funding, } \\
\text { data collection, statistical } \\
\text { analysis, data } \\
\text { interpretation, drafting } \\
\text { of the manuscript, } \\
\text { supervision of this } \\
\text { study, and administrative, } \\
\text { technical, or material } \\
\text { support }\end{array}$ \\
\hline
\end{tabular}

\section{References}

1. Huang CL, Wang YM, Li XW, et al. Clinical features of patients infected with 2019 novel coronavirus in Wuhan, China. Lancet 2020;395:497-506.

2. Li Q, Guan XH, Wu P, et al. Early transmission dynamics in Wuhan, China, of novel coronavirus-infected pneumonia. N Engl J Med 2020;382:1199-1207.

3. Wang DW, Hu B, Hu C, et al. Clinical characteristics of 138 hospitalized patients with 2019 novel coronavirus-infected pneumonia in Wuhan, China. JAMA 2020; 323:1061-1069.

4. Wang T, Zhu F, Cao Z, An Y, Gao Y, Jiang B. Comorbidities and multi-organ injuries in the treatment of COVID-19. Lancet 2020;395:e52.

5. Gustavo L, Peter A, Joachim B, et al. Infection risks among patients with multiple sclerosis treated with fingolimod, natalizumab, rituximab, and injectable therapies. JAMA Neurol 2019;77:184-191.

6. Wang C, Peter WH, Frederick GH, et al. A novel coronavirus outbreak of global health concern. Lancet 2020;395:470-473. 


\section{Neurology ${ }^{\odot}$ \\ Neuroimmunology \& Neuroinflammation}

Risk of COVID-19 infection in MS and neuromyelitis optica spectrum disorders Moli Fan, Wei Qiu, Bitao Bu, et al.

Neurol Neuroimmunol Neuroinflamm 2020;7;

DOI 10.1212/NXI.0000000000000787

This information is current as of June 4, 2020

Neurol Neuroimmunol Neuroinflamm is an official journal of the American Academy of Neurology.

Published since April 2014, it is an open-access, online-only, continuous publication journal. Copyright

Copyright $\odot 2020$ The Author(s). Published by Wolters Kluwer Health, Inc. on behalf of the American

Academy of Neurology.. All rights reserved. Online ISSN: 2332-7812.

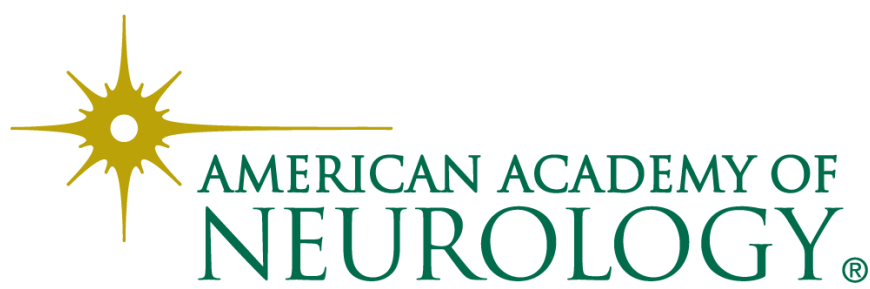




\section{Updated Information \& Services}

References

Citations

Subspecialty Collections

Permissions \& Licensing

\section{Reprints}

including high resolution figures, can be found at: http://nn.neurology.org/content/7/5/e787.full.html

This article cites 6 articles, 0 of which you can access for free at: http://nn.neurology.org/content/7/5/e787.full.html\#\#ref-list-1

This article has been cited by 5 HighWire-hosted articles: http://nn.neurology.org/content/7/5/e787.full.html\#\#otherarticles

This article, along with others on similar topics, appears in the following collection(s):

All Clinical Neurology

http://nn.neurology.org//cgi/collection/all_clinical_neurology All Demyelinating disease (CNS)

http://nn.neurology.org//cgi/collection/all_demyelinating_disease_cns Autoimmune diseases

http://nn.neurology.org//cgi/collection/autoimmune_diseases

\section{COVID-19}

http://nn.neurology.org//cgi/collection/covid_19

Devic's syndrome

http://nn.neurology.org//cgi/collection/devics_syndrome Multiple sclerosis

http://nn.neurology.org//cgi/collection/multiple_sclerosis

Information about reproducing this article in parts (figures,tables) or in its entirety can be found online at:

http://nn.neurology.org/misc/about.xhtml\#permissions

Information about ordering reprints can be found online: http://nn.neurology.org/misc/addir.xhtml\#reprintsus

Neurol Neuroimmunol Neuroinflamm is an official journal of the American Academy of Neurology.

Published since April 2014, it is an open-access, online-only, continuous publication journal. Copyright

Copyright $\odot 2020$ The Author(s). Published by Wolters Kluwer Health, Inc. on behalf of the American Academy of Neurology.. All rights reserved. Online ISSN: 2332-7812.

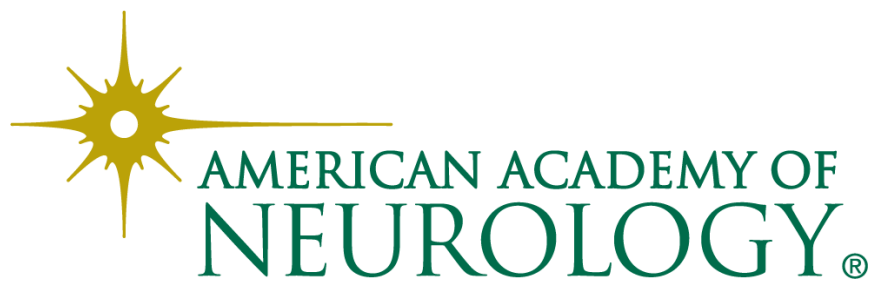

